\title{
KORELASI ANTARA PROFIL KOMPETENSI GURU SMK DENGAN HASIL BELAJAR SISWA
}

\author{
The Correlation Between the Academic Profile of Vocational School Teachers \\ and the Learning Outcomes of Vocational School Students
}

\author{
Sapon Suryopurnomo ${ }^{1)}$, Sumadi ${ }^{2)}$ \\ 1. PPPPTK Matematika, Depok, Sleman, DIY, +62274881717, 55283, Indonesia. \\ 2. PPPPTK Matematika, Depok, Sleman, DIY, +62274881717, 55283, Indonesia.
}

saponsuryopurnomo18@gmail.com

\begin{abstract}
This study describes the correlation between the academic competency profile of vocational school teachers and the learning outcomes of vocational school students in Indonesia. The academic profile includes teachers' ability to solve basic mathematics problems, national examination (UN) equivalent problems, and higher order thinking skills/HOTS problems. The learning outcomes of vocational school students in this study are based on the students' national examination(UN) results in 2018. This research is an Ex Post Facto study conducted on March to November 2019. The population of this study includes all vocational mathematics teachers in Indonesia. The sample of this study were 270 teachers from 22 districts of 17 provinces in Indonesia. The data of this study were analyzed by descriptive and correlational techniques. The results show that: 1) the ability of teachers to solve basic mathematics problems is 62,07; UN equivalent problems is 65,83; and HOTS problems is 18,22; 2) there is significant correlation between teachers' ability to solve basic mathematics problems, UN equivalent problems, and HOTS problems and students' ability of to solve UN problems.
\end{abstract}

Keywords: Academic Competency Profile, Mathematics Teacher, Vocational School

\begin{abstract}
ABSTRAK
Penelitian ini mendeskripsikan korelasi antara profil kemampuan akademik guru SMK dengan hasil belajar siswa SMK di Indonesia. Profil akademik tersebut mencakup kemampuan guru dalam memecahkan soal matematika dasar, soal-soal matematika setara Ujian Nasional, dan soal-soal High Order Thingking Skills (HOTs). Sedangkan hasil belajar siswa SMK dalam penelitian ini didasarkan pencapaian hasil Ujian Nasional tahun 2018. Penelitian ini menggunakan metode Ex Post Facto yang dilaksanakan mulai dari bulan Maret sampai November 2019. Populasi dari penelitian ini adalah seluruh guru matematika SMK di Indonesia. Sedangkan sampelnya adalah 270 guru dari 22 Kab./Kota 17 Propinsi di Indonesia. Data dari penelitian ini dianalisis menggunakan teknik Deskripsi dan Korelasi. Hasilnya menunjukkan: 1) kemampuan guru menyelesaikan masalah matematika dasar adalah 62,07; soal-soal setara UN 65,83; dan soal-soal HOTs 18,22. 2) Terdapat korelasi yang signifikan antara kemampuan guru menyelesaikan masalah matematika dasar, soal-soal setara UN dan soal-soal HOT dengan kemampuan siswa menyelesaikan soal-soal UN.
\end{abstract}

Kata kunci: Guru Matematika, Profil kemampuan akademik, SMK

\section{PENDAHULUAN}

Berbagai potensialitas dan nilai guna matematika sampai saat ini belum sepenuhnya dioptimalkan pemanfaatannya. Pembelajaran matematika di kelas belum mampu mendorong siswa-siswa Indonesia mencapai pretasi belajar optimal. Prestasi belajar matematika siswa, baik secara nasional maupun internasional, belum mencapai hasil seperti yang diharapkan. Berbagai studi, baik nasional maupun internasional, menunjukkan bahwa prestasi belajar matematika siswa-siswa di Indonesia termasuk kategori rendah.

Rendahnya prestasi belajar matematika harus menjadi perhatian seluruh pemangku kepentingan pendidikan matematika di Indonesia. Berbagai faktor yang mungkin menjadi penghambat terselenggara-nya pembelajaran matematika yang efektif harus diidentifikasi dan dicarikan solusinya. Prestasi belajar matematika bukan hanya merupakan fungsi tunggal yang dipengaruhi oleh satu faktor. Belajar matematika siswa merupakan simultan dari kontribusi beragam komponen, dari kurikulum, sarana prasarana, kultur sekolah, sampai ke guru, kepala sekolah, dan siswa sendiri. Keseluruhan variabel tersebut memberikan dampak baik secara langsung maupun tidak langsung terhadap pencapaian prestasi belajar matematika siswa. 
Banyak faktor yang berperan dalam kinerja guru matematika. Salah satu faktor penting yang mempengaruhi kualitas layanan guru ke siswa adalah penguasaan konten (Campbell, dkk, 2014: 423 -424). Guru harus menguasai dengan baik konten materi matematika yang merupakan bagian menu utama pembelajaran matematika di kelas. Lemahnya penguasaan konten oleh guru matematika berpotensi menyebabkan kesulitan transfer knowladge dari guru ke siswa. Miskonsepsi siswa terhadap materi matematika yang dipelajari juga berpotensi terjadi apabila guru tidak memiliki penguasaan yang baik terhadap konten materi yang diajarkan. Prestasi belajar siswa tentu juga akan terkendala disebabkan kurangnya penguasaan materi ajar oleh guru. Oleh karena itu, mencermati rendahnya pretasi belajar matematika siswa-siswa di Indonesia mendorong perlunya dilakukan kajian yang komprehensif tentang penguasaan konten matematika oleh guru.

Penelitian ini dilaksanakan dalam rangka melakukan pemetaan penguasaan kompetensi matematis guru. Profil penguasaan materi matematika oleh guru dapat digunakan sebagai bagian dari evaluasi terhadap rendahnya prestasi belajar matematika siswa. Temuan penelitian ini dapat dijadikan pijakan dalam pengembangan program-program peningkatan kompetensi guru matematika sehingga mewujudkan guru matematika yang kompeten. Pengembangan program pembinaan guru yang didasarkan pada temuan penelitian ini diharapkan dapat tepat sasaran sehingga mampu secara tepat memberikan solusi terhadap kebutuhan peningkatan kompetensi guru-guru matematika di Indonesia.

Penelitian ini difokuskan pada kajian terhadap penguasaan kemampuan matematis guru dalam 3 hal, yaitu: kemampuan dasar matematika guru, kemampuan guru dalam menyelesaikan soal-soal ujian nasional, dan kemampuan guru dalam menyelesaikan soal HOTs. Yang dimaksud dengan kemampuan dasar matematika disini adalah penguasaan konsep matematika sederhana yang menjadi dasar untuk memahami konsep matematika yang lebih tinggi atau kompleks. Kemampuan dasar dan matematika dasar guru sangat penting dikaji mengingat kedua kemampuan tersebut merupakan prasyarat mutlak bagi seorang guru agar dapat mengajar matematika, karena tanpa kemampuan dasar matematika dan matematika dasar bagaimana mungkin seseorang dapat menjadi guru matematika yang baik.

Yang dimaksud dengan kemampuan guru dalam menyelesaikan soal-soal ujian nasional disini adalah penguasaan guru terhadap soal-soal ujian Nasional atau soal-soal yang setara dengan ujian nasional. Kemampuan guru dalam menyelesaikan soal-soal ujian nasional juga penting dikaji mengingat rendahnya nilai ujian nasional matematika siswa.

Sedangkan yang dimaksud dengan kemampuan guru menyelesaikan soal HOTs disini adalah kemampuan guru dalam memecahkan atau menyelesaikan masalah matematika tingkat tinggi. Kemampuan ini pun penting dikaji mengingat saat ini sedang dilakukan reorientasi pembelajaran matematika di kelas berorientasi pengembangan HOTs siswa dan disinyalir salah satu penyebab rendahnya prestasi belajar matematika siswa dikarenakan mulai dimasukkannya soal-soal HOTs dalam pembelajaran dan penilaian matematika.

Sehubungan dengan tiga fokus penelitian di atas, rumusan masalah penelitian ini adalah:

(1) Bagaimana profil akademik guru SMK yang ditunjukkan dengan kemampuan dasar matematika, kemampuan menyelesaikan soal setara UN, dan kemampuan menyelesaikan soal HOTs?

(2) Apakah ada korelasi antara kemampuan dasar matematika guru dengan kemampuan guru dalam menyelesaikan soal setara UN, kemampuan dasar matematika guru dengan kemampuan guru dalam menyelesaikan soal HOTs, serta korelasi antara kemampuan guru dalam menyelesaikan soal setara UN dengan kemampuan guru dalam menyelesaikan soal HOTs?

(3) Apakah ada korelasi antara profil akademik guru dengan kemampuan siswa dalam menyelesaikan soal UN?

\section{METODE PENELITIAN}

Penelitian ini merupakan penelitian ex post facto untuk mengidentifikasi profil kemampuan dasar matematika guru, kemampuan menyelesaikan soal UN, dan HOTs, dan korelasi antar ketiga 
kemampuan guru tersebut, serta korelasinya dengan pencapaian nilai UN siswa. Peneliti tidak melakukan intervensi terhadap situasi lapangan, tetapi hanya berusaha mendapatkan gambaran berbagai kemampuan guru dan kaitannya dengan pencapaian nilai UN siswa. Penelitian dilaksanakan pada tahun 2019. Waktu pelaksanaan dari bulan Maret sampai dengan November 2019. Populasi penelitian ini meliputi seluruh guru matematika SMK di Indonesia. Sampel penelitian ini terdiri atas 270 orang guru, berasal dari 22 Kabupaten/Kota yang tersebar di 19 Propinsi di Indonesia.

Data penelitian ini dikumpulkan dengan teknik tes. Instrumen tes terdiri dari 3 (tiga) jenis, yaitu: tes kemampuan dasar matematika guru sebanyak 10 soal, tes kemampuan guru menyelesaikan soal setara UN sebanyak 20 soal, dan tes kemampuan guru menyelesaikan soal HOTs sebanyak 10 soal. Bentuk soalnya adalah pilihan ganda dengan disertai uraian jawaban. Instrumen-instrumen ini telah melalui proses validasi dan pengujian terbatas.

Data dalam penelitian ini dianalisis dengan teknik deskriptif dan korelasional. Teknik deskriptif digunakan untuk menganalisis data deskriptif terkait profil kemampuan matematika dasar guru, kemampuan guru menyelesaikan soal setara UN, dan kemampuan guru dalam menyelesaikan soal HOTs. Analisis korelasional dilakukan untuk menguji ada/tidaknya hubungan serta arah hubungan dari variabel-variabel yang diteliti (kemampuan dasar matematika, UN, dan HOTs). Uji korelasi dilakukan sepasang-sepasang, yaitu: kemampuan dasar matematika dengan UN; kemampuan dasar matematika dengan HOTs serta UN dengan HOTs. Ketiga uji korelasi ini menggunakan Uji Korelasi Spearman rho. Selain itu juga dilakukan analisis korelasional antara profil akademik guru dengan kemampuan siswa dalam menyelesaikan soal UN, dengan menggunakan Uji Korelasi Pearson. Selang Koefisien Korelasi yang digunakan adalah sebagai berikut:

\begin{tabular}{lll}
\hline No & Selang Korelasi & Kategori \\
\hline 1 & $0,81-1,00$ & Sangat kuat \\
\hline 2 & $0,61-0,80$ & Kuat \\
\hline 3 & $0,41-0,60$ & Sedang \\
\hline 4 & $0,21-0,40$ & Lemah \\
\hline 5 & $0,00-0,20$ & Sangat lemah \\
\hline
\end{tabular}

\section{HASIL DAN PEMBAHASAN}

\subsection{Grafik Profil Kompetensi Akademik}

Berdasarkan data hasil penelitian yang diperolah, profil kemampuan dasar matematika guru SMK, kemampuan menyelesaikan soal setara UN, dan kemampuan menyelesaikan soal HOTs dapat digambarkan dengan grafik berikut.

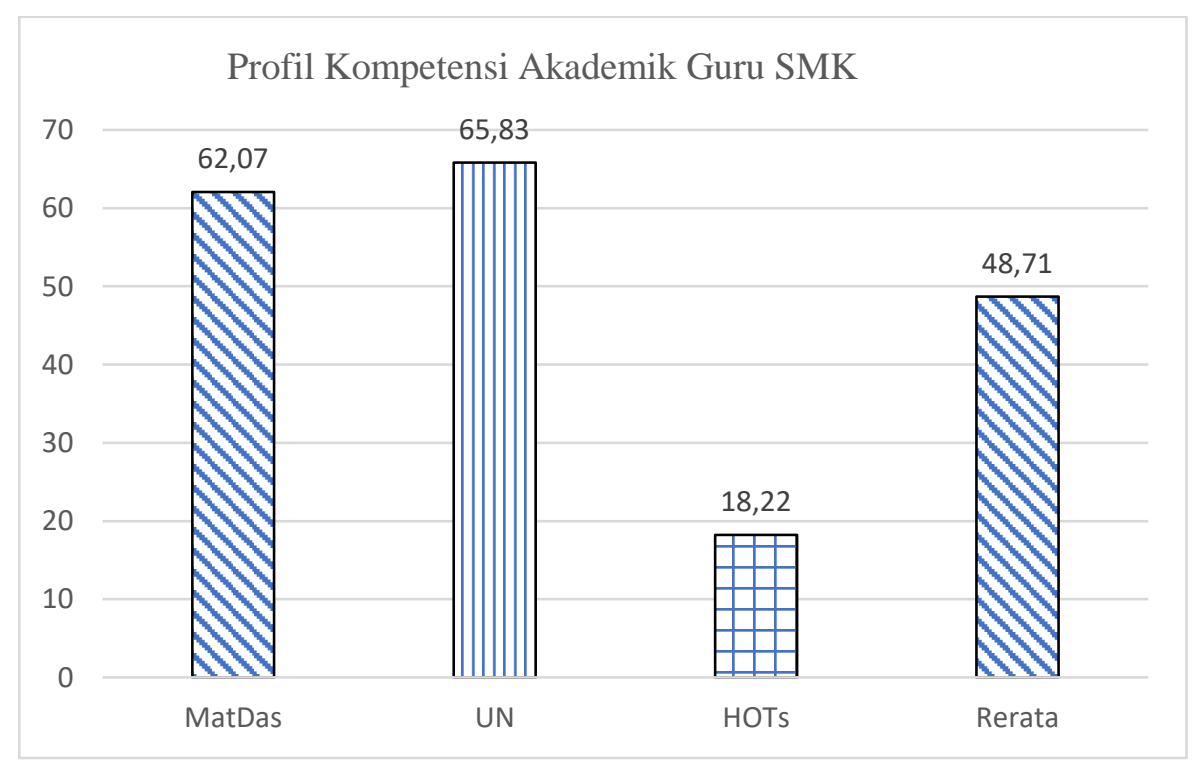


Gambar 1. Grafik Profil Kompetensi Akademik Guru SMK

Berdasarkan hasil analisis yang telah dilakukan diperoleh bahwa: kemampuan guru dalam menyelesaikan soal matematika dasar adalah 62.07, soal setara UN 65.83, dan soal HOTs 18.22. Hasil ini menunjukkan bahwa secara umum kemampuan guru masih perlu ditingkatkan, terutama kemampuan menyelesaikan soal-soal HOTs.

\subsection{Hasil Uji Hipotesis Korelasi}

\subsubsection{Korelasi antara kemampuan matematika dasar guru dengan kemampuan guru dalam menyelesaikan soal-soal setara UN}

Korelasi antara kemapuan matematika dasar guru dengan guru menyelesaikan soal-soal setara UN disajikan pada table 1 berikut ini.

Tabel 1 Korelasi antara kemampuan dasar matematika guru dengan kemampuan guru menyelesaikan soal-soal setara UN

\begin{tabular}{lllrr}
\hline & & DasMatGuru & \multicolumn{1}{c}{ UN } \\
\hline Spearman's rho & DasMatGuru & Koefisien Korelasi & 1,000 & 0,549 \\
& & Signifikan (2-arah) & - & 0,000 \\
& & $\mathrm{~N}$ & 270 & 270 \\
\hline \multirow{2}{*}{ UNGuru } & Koefisien Korelasi & 0,549 & 1,000 \\
& & Signifikan (2-arah) & 0,000 & - \\
& & $\mathrm{N}$ & 270 & 270 \\
\hline
\end{tabular}

Diperoleh koefisien korelasi 0.549, dengan Sig kurang dari 0.05. Hal ini menunjukkan bahwa ada korelasi yang positif sedang $(0,41-0,60)$ dan signifikan antara kemampuan matematika dasar guru dengan kemampuan guru dalam menyelesaikan soal UN matematika SMK. Dengan demikian apabila kemampuan matematika dasar guru semakin tinggi maka kemampuan menyelesaikan soal UN matematika SMK juga semakin tinggi, begitu juga sebaliknya.

\subsubsection{Korelasi antara kemampuan matematika dasar guru dengan kemampuan guru dalam menyelesaikan soal-soal HOTs}

Korelasi antara kemampuan matematika dasar guru dengan kemampuan guru menyelesaikan soalsoal HOTs disajikan pada table 2 berikut ini.

Tabel 2 Korelasi antara kemampuan matematika dasar guru dengan kemampuan guru menyelesaikan soal-soal HOTs

\begin{tabular}{lllrr}
\hline & & DasMatGuru & HOTsGuru \\
\hline Spearman's rho & DasMatGuru & Koefisien Korelasi & 1,000 & 0,369 \\
& & Signifikan (2-arah) & - & 0,000 \\
& & N & 270 & 270 \\
\hline \multirow{2}{*}{ HOTsGuru } & Koefisien Korelasi & 0,369 & 1,000 \\
& & Signifikan (2-arah) & 0,000 & - \\
& & $\mathrm{N}$ & 270 & 270 \\
\hline
\end{tabular}

Koefisien korelasi antara kemampuan matematika dasar guru dengan kemampuan guru menyelesaikan soal-soal HOTs adalah 0.369 dengan Sig kurang dari 0.05. Hal ini menunjukkan bahwa ada korelasi yang positif lemah $(0,21-0,40)$ dan signifikan antara kemampuan matematika dasar guru dengan kemampuan guru dalam menyelesaikan soal HOTS matematika SMK. Dengan demikian, apabila kemampuan matematika dasar guru semakin tinggi maka kemampuan menyelesaikan soal HOTS matematika SMK juga semakin tinggi, begitu juga sebaliknya. 


\subsubsection{Korelasi antara kemampuan guru menyelesaikan soal-soal setara UN dengan kemampuan guru dalam menyelesaikan soal-soal HOTs}

Korelasi antara kemampuan guru menyelesaikan soal-soal setara UN dengan kemampuan guru menyelesaikan soal-soal HOTs disajikan pada table 3 berikut ini.

Tabel 3 Korelasi antara kemampuan guru menyelesaikan soal-soal setara UN dengan kemampuan guru menyelesaikan soal-soal HOTs

\begin{tabular}{lllrr}
\hline & & UNGuru & HOTsGuru \\
\hline Spearman's rho & UNGuru & Koefisien Korelasi & 1,000 & 0,416 \\
& & Signifikan (2-arah) & - & 0,000 \\
& N & 270 & 270 \\
\hline & HOTsGuru & Koefisien Korelasi & 0,416 & 1,000 \\
& & Signifikan (2-arah) & 0,000 & - \\
& $\mathrm{N}$ & 270 & 270 \\
\hline
\end{tabular}

Koefisien korelasi 0.416, dengan Sig kurang dari 0.05. Hal ini menunjukkan bahwa ada korelasi yang positif sedang $(0,41-0,60)$ dan signifikan antara kemampuan guru menyelesaikan soal-soal setara UN dengan kemampuan guru menyelesaikan soal-soal HOTs. Dengan demikian, apabila kemampuan guru dalam menyelesaikan soal UN semakin tinggi maka kemampuan menyelesaikan soal HOTS matematika SMK juga semakin tinggi, begitu juga sebaliknya.

Adanya korelasi yang positif dan signifikan antar kemampuan guru, baik itu dalam kemampuan matematika dasar, kemampuan menyelesaikan soal-soal setara UN atau pun kemampuan menyelesaikan soal-soal HOTs berimplikasi bahwa pembinaan guru harus dilakukan secara komprehensif sehingga guru dapat meningkatkan kompetensinya secara menyeluruh.

Kompetensi guru di suatu bagian akan memberikan dampak langsung bagi penguasaan kompetensi guru pada bagian lain. Oleh karena itu, program pembinaan guru yang menyasar pada domain utuh kemampuan guru akan memberikan dampak simultan bagi peningkatan kompetensi guru.

\subsubsection{Korelasi antara kemampuan matematika dasar guru dengan hasil UN Siswa SMK}

Korelasi antara kemampuan matematika dasar guru dengan hasil UN siswa SMK disajikan pada tabel 4 berikut ini.

Tabel 4 Korelasi antara kemampuan matematika dasar guru dengan hasil UN siswa SMK

\begin{tabular}{llrr}
\hline & & MatDasGuru & \multicolumn{1}{c}{ UNSiswa } \\
\hline MatDasGuru & Korelasi Pearson & 1 & 0,304 \\
& Signifikan (2-arah) & & 0,000 \\
& Jumlah Kuadrat dan & 129638,519 & 6496,831 \\
& Cross-Product & & \\
& Kovarian & 481,928 & 24,152 \\
& N & 270 & 270 \\
\hline UNSiswa & Korelasi Pearson & 0,304 & 1 \\
& Signifikan (2-arah) & 0,000 & \\
& Jumlah Kuadrat dan & 6496,831 & 3511,645 \\
& Cross-Product & & \\
& Kovarian & 24,152 & 13,054 \\
& N & 270 & 270 \\
\hline
\end{tabular}

Koefisien korelasi 0.304, dengan Sig kurang dari 0.05 menunjukkan adanya korelasi positif lemah dan signifikan antara kemampuan matematika dasar guru dengan hasil UN siswa SMK. Dengan demikian, apabila kemampuan matematika dasar guru semakin tinggi, maka hasil UN siswa SMK juga semakin tinggi, begitu juga sebaliknya. 


\subsubsection{Korelasi antara kemampuan guru menyelesaikan soal-soal setara UN dengan hasil UN Siswa SMK}

Korelasi antara kemampuan guru menyelesaikan soal-soal setara UN dengan hasil UN siswa SMK disajikan pada tabel 5 berikut ini.

Tabel 5 Korelasi antara kemampuan guru menyelesaikan soal-soal setara UN dengan hasil UN siswa SMK

\begin{tabular}{llrr}
\hline & & \multicolumn{1}{c}{ UNGuru } & \multicolumn{1}{c}{ UNSiswa } \\
\hline UNGuru & Korelasi Pearson & 1 & 0,446 \\
& Signifikan (2-arah) & & 0,000 \\
& Jumlah Kuadrat dan & 167537,500 & 10818,550 \\
& Cross-Product & & \\
& Kovarian & 622,816 & 40,218 \\
& $\mathrm{~N}$ & 270 & 270 \\
\hline UNSiswa & Korelasi Pearson & 0,446 & 1 \\
& Signifikan (2-arah) & 0,000 & \\
& Jumlah Kuadrat dan & 10818,550 & 3511,645 \\
& Cross-Product & & \\
& Kovarian & 40,218 & 13,054 \\
& N & 270 & 270 \\
\hline
\end{tabular}

Koefisien korelasi antara kemampuan guru menyelesaikan soal-soal setara UN dengan hasil UN siswa SMK adalah 0.446 dengan Sig kurang dari 0.05. Dapat dinyatakan bahwa ada korelasi positif sedang dan signifikan antara kemampuan guru dalam menyelesaikan soal-soal setara UN dengan hasil UN siswa SMK.Dengan demikian, apabila kemampuan guru menyelesaikan soal-soal setara UN semakin tinggi maka hasil UN siswa SMK juga semakin tinggi, begitu juga sebaliknya.

\subsubsection{Korelasi antara kemampuan guru menyelesaikan soal-soal HOTs dengan hasil UN Siswa SMK}

Korelasi antara kemampuan guru menyelesaikan soal-soal HOTs dengan hasil UN siswa SMK disajikan pada tabel 6 berikut ini.

Tabel 6 Korelasi antara kemampuan guru menyelesaikan soal-soal HOTs dengan hasil UN siswa SMK

\begin{tabular}{llrr}
\hline & & HOTsGuru & UNSiswa \\
\hline HOTsGuru & Korelasi Pearson & 1 & 0,232 \\
& Signifikan (2-arah) & & 0,000 \\
& Jumlah Kuadrat dan & 54946,667 & 3229,573 \\
& Cross-Product & & \\
& Kovarian & 204,263 & 12,006 \\
& N & 270 & 270 \\
\hline UNSiswa & Korelasi Pearson & 0,232 & 1 \\
& Signifikan (2-arah) & 0,000 & \\
& Jumlah Kuadrat dan & 3229,573 & 3511,645 \\
& Cross-Product & & \\
& Kovarian & 12,006 & 13,054 \\
& N & 270 & 270 \\
\hline
\end{tabular}

Diperoleh koefisien korelasi 0.232, dengan Sig kurang dari 0.05. Hal ini menunjukkan bahwa ada korelasi positif lemah dan signifikan antara kemampuan guru menyelesaikan soal-soal HOTs dengan hasil UN siswa SMK. Dengan demikian apabila kemampuan guru dalam menyelesaikan soal-soal HOTs semakin tinggi maka hasil UN siswa SMK juga semakin tinggi, begitu juga sebaliknya. 
Secara umum dapat dilihat bahwa profil akademik guru yang meliputi kemampuan dasar matematika, kemampuan menyelesaikan soal-soal setara UN, dan kemampuan menyelesaiakan soal HOTs berhubungan yang signifikan dengan hasil belajar siswa SMK yang diukur melalui UN.

Hasil penelitian ini senada dengan hasil penelitian diberbagai negara mengenai keterkaitan antara kompetensi akademik guru dengan hasil belajar siswa pada berbagai mata pelajaran. Diantara Abdullah et.al (2017) yang meneliti tentang tingkat pengetahuan dan penerapan HOTs guru matematika di Malaysia menyatakan tingkat pengetahuan dan praktik guru matematika sekolah menengah tentang penerapan HOTS dapat mempegaruhi tingkat pemahaman dalam pembelajaran dan pengajaran matematika

Hasil penelitian Nbina (2012) mengenai hubungan antara kompetensi guru dengan hasil belajar siswa kimia di Nigeria juga menunjukkan adanya hubungan yang signifikan antara kompetensi guru dan hasil belajar siswa secara akademik. Hasil penelitian mengenai hubungan antara kompetensi guru, iklim sekolah dan perfoma akademik siswa yang dilakukan oleh Rabo (2018) di Nigeria menunjukkan bahwa Kompetensi guru juga sangat menentukan hasil belajar siswa secara akademik. Lebih lanjut dikemukakan bahwa hal ini menyiratkan kompetensi guru, pengetahuan yang baik tentang materi pelajaran dan hubungan guru dengan siswa dapat meningkatkan hasil belajar siswa secara akademik.

Kulshrestha dan Pandey (2013) menyatakan bahwa banyak faktor yang berkontribusi terhadap kualitas pengajaran, misalnya kompetensi profesional guru yang meliputi pengetahuan materi pelajaran, pengetahuan konten pedagogis, pengetahuan mengajar dan belajar, pengetahuan kurikuler, pengalaman mengajar, dan status sertifikasi.

Hal yang sama dinyatkan juga oleh Thakur dan Shekhawat (2014) bahwa salah satu unsur kompetensi profesional guru adalah penguasaan materi pembelajaran (subject knowledge). Kompetensi ini mempunyai kontribusi yang tinggi dalam pencapaian keberhasil siswa secara akademik. Lebih lanjut Takhur dan Sekhawat (2014) menyatakan bahwa kompetensi professional mendapat opini dari siswa yang paling positif di peringkat pertama, sedangkan kompetensi pedagogik menempati peringkat yang terakhir. Peringkat kedua dan ketiga ditempati oleh kompetensi personal dan komptensi sosial.

Berbagai hasil penelitian di atas menggambarkan betapa hubungan profil akademik sebagai salah satu komponen kompetensi profesioanl guru erat kaitannya dengan hasil belajar siswa. Oleh karena itu diperlukan suatu upaya yang sungguh-sungguh untuk meningkat-kan kompetensi tersebut agar hasil belajar siswa bisa meningkat.

Peningkatan kompetensi guru ini sangat diperlukan mengingat bahwa keberhasiln pembelajaran di kelas sangat dipengaruhi oleh komptensi gurunya. Salah satu faktor paling dominan yang mempengaruhi hasil belajar matematika siswa adalah guru. Kompetensi dan kinerja guru berpengaruh besar, baik secara langsung maupun tidak langsung, terhadap prestasi belajar siswa. Hattie, J. (2003: 3) menunjukkan bahwa guru merupakan salah satu faktor dominan yang mempengaruhi prestasi belajar siswa. Guru memberikan sumbangan pengaruh sebesar $30 \%$ terhadap pencapaian prestasi siswa, faktor siswa 50\%, rumah 5-10\%, sekolah 5-10\%, teman $5-10 \%$, dan kepala sekolah. Hal ini selaras dengan pendapat (Cobb \& Hodge, 2002) yang menyatakan bahwa guru adalah sumber yang paling penting untuk mengembangkan identitas matematika siswa. Oleh karena itu, keberhasilan pembelajaran matematika sekolah salah satunya ditentukan oleh kualitas guru-guru, baik dalam hal penguasaan materi maupun cara mengajarkannya. 


\section{SIMPULAN DAN SARAN}

Hasil penelitian menunjukkan:

1) kemampuan guru SMK dalam menyelesaikan soal matematika dasar adalah 62.07, soal setara USBN 65.83, soal HOTs 18.22, dan rerata 48,71.

2) ada korelasi yang signifikan antara kemampuan matematika dasar guru SMK dengan kemampuan menyelesaikan soal setara UN sebesar 0.549, matematika dasar dengan HOTs sebesar 0.369, dan soal setara UN dengan HOT sebesar 0.416 .

3) ada korelasi antara profil kompetensi akademik guru dengan hasil belajar siswa SMK, yaitu korelasi antara kemampuan matematika guru dalam menyelesaikan soal matematika dasar dengan hasil UN siswa sebesar 0.304, soal setara UN guru dengan hasil UN siswa sebesar 0.446, dan HOTs dengan UN siswa sebesar 0.232 .

Berdasarkan hasil penelitian ini dapat diberikan beberapa saran sebagai berikut.

1. Program pengembangan dan pemberdayaan guru matematika harus terus ditingkatkan sebagai bagian dari pembinaan guru agar kompetensi guru semakin meningkat.

2. Pembinaan guru harus dilakukan secara terus-menerus dan komprehensif sehingga guru dapat meningkatkan kompetensinya secara menyeluruh. Kompetensi guru di suatu bagian akan memberikan dampak langsung bagi penguasaan kompetensi guru pada bagian lain. Oleh karena itu, program pembinaan guru yang menyasar pada domian utuh kemampuan guru akan memberikan dampak simultan bagi peningkatan kompetensi guru. Semua tindakan ini diharapkan dapat berimplikasi kepada adanya peningkatan yang terus-menerus terhadap hasil UN siswa.

3. Perlu dilakukan pemetaan menyeluruh kompetensi guru matematika sehingga diperoleh data yang jelas dan akurat sebagai dasar pijakan pengembangan dan pelaksanaan program-program pembinaan guru matematika di Indonesia.

\section{DAFTAR PUSTAKA}

Abdullah, A.H., Mochtar, M., Halim, N.D.A., Ali, D.F., Tahir, L.M., and Kohar, U.H.A. 2017. Mathematics Teachers' Level of Knowledge and Practice on the Implementation of HigherOrder Thinking Skills (HOTS). EURASIA Journal of Mathematics Science and Technology Education 13(1), PP 3-17

Campbell, P.F., dkk. (2014). The Relationship Between Teachers' Mathematical Content and Pedagogical Knowledge, Teachers' Perceptions, and Student Achievement. Journal for Research in Mathematics Education, 45(4) 419-459

Cobb, P., \& Hodge, L. L. (2002). A relational perspective on issues of cultural diversity and equity as they play out in the mathematics classroom. Mathematical Thinking and Learning, 4 (1) 249-284

Hattie, J. (2003). Teachers Make a Difference: What is the research evidence? Australian Council for Educational Research Annual Conference on: Building Teacher Quality

Kulshrestha, A.K. and Pandey, K. (2013). Teacher Training and Professional Competences. Voice of Research, Vol. 1 Issue 4, PP 29-33

Nbina, J.B. 2012. Teachers' Competences and Student Academic Performances in Senior Scondary Schools Chemistry: Is There Realtionship? Global Journal of Educational Research Vol 11, No. 1 , PP $15-18$

Rabo, U.M. 2018. Relationship Between Teacher Competence, School Climate and Academic Performance of Public Senior Secondary School Students in Sokoto State, Nigeria. International Journal of Humanities and Social Science Invention (IJHSSI) Volume 7 Issue 11 Ver. I, PP 34-40

Thakur, A., and Shekhawat, M. 2014. The Study of Different Components of Teacher Competencies and their Effectiveness on Student. International Journal of Engineering Research \& Technology (IJERT) Vol. 3 Issue 7, PP 1426-1428 